JAMP: Jurnal Adminitrasi dan Manajemen Pendidikan

Volume 2 Nomor 3 September 2019, Hal : 83-89

Tersedia Online di http://journal2.um.ac.id/index.php/jamp/

ISSN 2615-8574 (online)

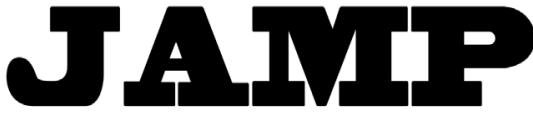

JURNAL ADMINISTRASI DAN MANAJEMEN PENDIDIKAN

\title{
HUBUNGAN KEIKUTSERTAAN KEGIATAN EKSTRAKURIKULER DAN PRESTASI BELAJAR PESERTA DIDIK
}

\author{
Messia Luki Kartikasari, Sultoni, Raden Bambang Sumarsono \\ Jurusan Administrasi Pendidikan Fakultas Ilmu Pendidikan \\ Universitas Negeri Malang Jl.Semarang 5 Malang \\ E-mail:messialuki97@gmail.com
}

\begin{abstract}
The purpose of this study was to describe: (1) the level of participation of extracurricular activities of SMPN Trenggalek district students; (2) the level of learning achievement of SMPN Trenggalek district students; (3) the relationship between the participation of extracurricular activities and the students' learning achievements of SMPN Treggalek district. This study used a quantitative approach with a simple linear regression design. The sampling technique used in this study was cluster sampling by taking a representative from each region contained in the population. The sample for the participation of extracurricular activities was 284 students from a population of 978 students which located in SMPN Trenggalek district. The instrument used in data collection was in the form of a questionnaire. The data analysis technique used in this study was descriptive technique, simple linear regression. The conclusions of this study were: (1) the level of participation of extracurricular activities of SMPN Trenggalek students was in the medium category; (2) the level of learning achievements of SMPN Trenggalek students was in the medium category; (3) simultaneously, there was a positive relationship between the participation of extracurricular activities with students' learning achievements of SMPN Trenggalek district.
\end{abstract}

Keyword: participation of extracurricular activities; learning achievement

\begin{abstract}
Abstrak: Tujuan penelitian ini untuk mengetahui : (1) tingkat keikutsertaan peserta didik pada kegiatan ekstrakurikuler di SMP Negeri Kabupaten Trenggalek; (2) tingkat prestasi belajar peserta didik di SMP Negeri Kabupaten Trenggalek; (3) hubungan tingkat keikutsertaan kegiatan ekstrakurikuler dan prestasi belajar peserta didik di SMP Negeri Kabupaten Trenggalek.Penelitian ini menggunakan pendekatan kuantitatif dengan rancangan regresi linier sederhana. Teknik pengambilan sampel yang digunakan dalam penelitian ini adalah teknik area (cluster) sampling yaitu teknik sampling dengan mengambil wakil dari setiap wilayah yang terdapat dalam populasi tersebut. Sampel keikutsertaan kegiatan ekstrkurikuler terdapat 284 peserta didik dari populasi sejumlah 978 peserta didik dengan lokasi penelitian di SMP Negeri Kabupaten Trenggalek. Instrumen yang digunakan dalam pengumpulan data yakni berupa angket. Teknik analisis data yang digunakan dalam penelitian ini yaitu teknik deskriptif, dan regresi linier sederhana. Simpulan penelitian ini yaitu: (1) tingkat keikutsertaan peserta didik pada kegiatan ekstrakurikuler di SMP Negeri Kabupaten Trenggalek dalam kategori sedang; (2) tingkat prestasi belajar peserta didik di SMP Negeri Kabupaten Trenggalek dalam kategori sedang; (3) secara simultan terdapat hubungan yag positif antara tingkat keikutsertaan kegiatan ekstrakurikuler dan prestasi belajar peserta didik di SMP Negeri Kabupaten Trenggalek.
\end{abstract}

Kata Kunci: keikutsertaan kegiatan ekstrakurikuler; prestasi belajar

Prestasi belajar adalah hasil yang diperoleh peserta didik berupa kesan-kesan yang mengakibatkan perubahan dalam diri individu sebagai hasil dari aktivitas belajar (Djamarah, 2012). Sementara itu, Surya (2007) mengemukakan bahwa presetasi belajar merupakan hasil dari perubahan tingkah laku yang menyangkut ilmu pengetahuan, keterampilan, dan juga sikap dengan melalui berbagai proses yang 
telah ditentukan, dan juga sebagai perolehan hasil dari pengalaman individu melalui interaksi dengan lingkunganya.

Proses pendidikan harus bisa menyeimbangkan antara otak kanan dan otak kiri. Otak kanan mempunyai fungsi yang berbeda dengan otak kiri, fugsi otak kanan termasuk dalam, emosi, kreativitas, sosialisasi, khayalan, musik, dan warna. Belahan otak kanan adalah sumber intuisi, insight, kiasan, dan imajinasi (Kadir, 2010). Menurut Kadir (2010) otak kiri mempunyai fusngi yaitu, kemampuan dalam logika (berfikir logis), kemampuan berbahasa (berbicara, menulis, dan membaca), kemampuan berpikir linier, sistematis dan rasional, dua kemampuan lainnya adalah detail dan analisis. Orang-orang dengan fungsi otak kiri dominan lebih mengedepankan logika dan fakta. Belahan otak yang seimbang (kanan dan kiri) akan memberikan sumber kemampuan dan kecakapan yang lebih dari sekadar maksimal. Untuk itu, di sekolah perlu menyelenggarakan kegiatan ekstrakurikuler.

Keikutsertaan adalah bagian dari partisipasi yang ditunjukkan dengan perilaku fisik dan psikisnya. Pernyataan ini diambil dari teori partisipasi yang dijelaskan menurut (Hasibuan dan Moedjiono, 2006) partisipasi peserta didik berarti keikutsertaan peserta didik dalam suatu kegiatan yang ditunjukkan dengan perilaku fisik dan psikisnya. Kegiatan ekstrakurikuler merupakan sebuah kegiatan yang ada di sekolah yang pelaksanaan kegiatannya tidak di atur oleh kurikulum menurut Zulkarnain (2015).

Berikut penelitian terdahulu yang digunakan sebagai acuan dan penguat dalam penelitian ini. Menurut hasil peneliti Hardianus (2014) hasil analisis data penelitian dapat disimpulkan bahwa ada hubungan yang positif antara kegiatan ekstrakulikuler dengan prestasi belajar siswa SMK Perindustrian Yogyakarta. Adanya hubungan yang positif ini membantu peneliti baru untuk memperkuat penelitiannya. Hasi penelitian berikutnya adalah Nasehudin (2010) berdasarkan hasil analisis data yang diperoleh dapat diambil kesimpulan bahwa ada hubungan yang bersifat positif antara kegiatan ekstrakurikuler dengan prestasi belajar siswa MTs.

Penulis mencantumkan informasi yang diperoleh dari Radar Tulungagung berita tentang salah satu dari prestasi dalam ekstrakurikuler yang diraih oleh SMPN 4 Trenggalek yang berada di Jalan Pahlawan Gang 6, Karangsoko, Trenggalek. Pada Mei 2018, siswa atas nama Maheswari Hemas Widyanahdah kelas VII A merai juara 1 Story Telling (lomba dalam bercerita atau mendongeng) di ajang Festival dan Lomba Seni Siswa Nasional (FLS2N). Kejuaraan ini di raihnya dengan minat dalam belajar Bahasa Inggris yang tinggi, ditambah dengan hobinya membaca dan menulis cerita dengan latar luar negeri membuatnya terlihat begitu mudah saat bercerita di depan juri. Selain itu Maheswari mengikuti olimpiade olahraga siswa nasional (O2SN) tingkat kabupaten dan berhasil meraih juara II. Selanjutnya prestasi diperoleh dari SMPN 1 Suruh, Kecamatan Suruh, Kabupaten Trenggalek memperoleh juara II OSN Matematika tingkat Kabupaten/Kota dan mendapat penghargaan dari Dinas Pendidikan Pemuda dan Olah Raga atau di singkat Disdikpora (http://dapo.dikdasmen.kemdikbud.go.id/pd).

Penelitian ini mengungkap hubungan keikutsertaan kegiatan ekstrakurikuler dan prestasi belajar peserta didik di SMP Negeri Kabupaten Trenggalek. Penelitian ini dilakukan di 5 sekolah SMP Negeri kabupaten Trenggalek. Tujuan penelitian ini untuk mendiskripsikan: (1) tingkat keikutsertaan kegiatan ekstrakurikuler peserta didik di SMP Negeri Kabupaten Trenggalek; (2) tingkat prestasi belajar peserta didik SMP Negeri Kabupaten Trenggalek; (3) hubungan keikutsertaan kegiatan ekstrakurikuler dan prestasi belajar peserta didik di SMP Negeri Kabupaten Trenggalek.

\section{METODE}

Penelitian ini menggunakan pendekatan penelitian kuantitatif, dimana data yang digunakan dalam penelitian ini menggunakan angka yang memiliki tujuan untuk menjelaskan kejadian/fenomena dari hasil obserasi yang ada di lapangan (Firdaus, 2012). Penelitian ini merupakan penelitian yang diajukan menggunakan populasi atau sampel tertentu sebagai bahan pengumpulan data serta menggunakan instrumen penelitian dan analisis data yang bersifat statistik.

Penelitian ini menggunakan sampel sejumlah 284 dengan jumlah populasi 978 peserta didik dengan lokasi penelitian di 5 SMP Negeri Kabupaten Trenggalek. Instrumen penelitian yang digunakan dalam 
penelitian ini menggunakan metode angket atau kuisioner dan metode dokumentasi untuk mencari data nilai raport peserta didik. Menurut Sugiyono (2014) menyatakan bahwa instrumen penelitian adalah suatu alat pengumpulan data yang digunakan untuk mengukur fenomena yang akan diteliti. Peneliti menggunakan model penyusunan kuesioner yang didasarkan pengembangan skala Likert. Menurut Sugiyono (2014) Skala Likert digunakan untuk mengukur sikap, pendapat, dan persepsi seseorang atau kelompok orang tentang fenomena sosial. Dengan menggunakan Skala Likert, maka variabel yang akan diukur dijabarkan melalui indikator variabel.

Teknik analisis data dapat digunakan dalam mengelola hasil penelitian bermacam-macam jenis/ bentuknya. Setelah melakukan penyebaran angket tersebut dikumpulkan kembali, diolah dan dianalisis dengan menggunakan teknik analisis data. Menurut Wiyono (2007: 60), analisis data pada hakikatnya adalah "mengolah angka-angka yang diperoleh dari skor yang mudah dibaca dan disimpulkan". Uji analisis yang digunakan adalah teknik persentase. Teknik persentase adalah teknik untuk mengetahui gambaran secara kuantitatif mengenai kondisi dan masing-masing variabel. Teknik analisis yang digunakan dalam penelitian ini adalah sebagi berikut. Teknik analisis yang digunakan dalam penelitian ini yaitu teknik analisis statistik deskriptif dan regresi sederhana.

\section{HASIL}

\section{Keikutsertaan Peserta Didik pada Kegiatan Ekstrakurikuler di SMP Negeri Kabupaten Trenggalek}

Diketahui pada interval 4,00 - 10,40 didapat sebanyak 50 responden $(13,3 \%)$ yang menyatakan bahwa kegiatan ekstrakurikuler SMP Negeri Kabupaten Trenggalek masuk dalam kategori sangat rendah. Interval 10,41 - 16,81 didapat sebanyak 97 responden $(25,9 \%)$ yang menyatakan bahwa kegiatan ekstrakurikuler SMP Negeri Kabupaten Trenggalek masuk dalam kategori rendah. Interval 16,82 23,22 didapat sebanyak 152 responden (40,5\%) yang menyatakan bahwa kegiatan ekstrakurikuler SMP Negeri Kabupaten Trenggalek masuk dalam kategori sedang. Interval 23,23 - 29,63 didapat sebanyak 56 responden $(14,9 \%)$ yang menyatakan bahwa kegiatan ekstrakurikuler SMP Negeri Kabupaten Trenggalek masuk dalam kategori tinggi. Interval 29,64 - 36,04 didapat sebanyak 20 responden $(5,3 \%)$ yang menyatakan bahwa kegiatan ekstrakurikuler SMP Negeri Kabupaten Trenggalek masuk dalam kategori sangat tinggi. Mean (rata-rata) pada variabel kegiatan ekstrakurikuler SMP Negeri Kabupaten Trenggalek diperoleh hasil sebesar 18,09 dan berada pada interval 16,82 -23,22 sehingga masuk dalam kategori sedang.

Tabel 1 Keikutsertaan Kegiatan Ekstrakurikuler Siswa SMP Negeri Kabupaten

\begin{tabular}{lcccc}
\hline No & Interval & Kategori & Frekuensi & Persentase \\
\hline 1 & $4,00-10,40$ & Sangat rendah & 50 & 13,3 \\
2 & $10,41-16,81$ & Rendah & 97 & 25,9 \\
3 & $16,82-23,22$ & Sedang & 152 & 40,5 \\
4 & $23,23-29,63$ & Tinggi & 56 & 14,9 \\
5 & $29,64-36,04$ & Sangat Tinggi & 20 & 5,3 \\
\hline & Total & & 375 & 100 \\
\hline
\end{tabular}

\section{Prestasi Belajar Peserta Didik SMP Negeri Kabupaten}

Diketahui pada interval 66,00 - 71,60 didapat sebanyak 23 responden $(6,1 \%)$ yang menyatakan bahwa prestasi belajar siswa SMP Negeri Kabupaten Trenggalek masuk dalam kategori sangat rendah. Interval 71,61 - 77,21 didapat sebanyak 90 responden (24,0\%) yang menyatakan bahwa prestasi belajar siswa SMP Negeri Kabupaten Trenggalek masuk dalam kategori rendah. Interval 77,22 - 82,82 didapat sebanyak 133 responden $(35,5 \%)$ yang menyatakan bahwa prestasi belajar siswa SMP Negeri Kabupaten Trenggalek masuk dalam kategori sedang. Interval 82,83 - 88,43 didapat sebanyak 97 responden 
$(25,9 \%)$ yang menyatakan bahwa prestasi belajar siswa SMP Negeri Kabupaten Trenggalek masuk dalam kategori tinggi. Interval 88,44 - 94,04 didapat sebanyak 32 responden $(8,5 \%)$ yang menyatakan bahwa prestasi belajar siswa SMP Negeri Kabupaten Trenggalek masuk dalam kategori sangat tinggi. Mean (rata-rata) pada variabel prestasi belajar diperoleh hasil sebesar 80,29 dan berada pada interval 77,22 - 82,82 sehingga masuk dalam kategori sedang.

Tabel 2 Prestasi Belajar Siswa SMP Negeri Kabupaten

\begin{tabular}{lcccc}
\hline No & Interval & Kategori & Frekuensi & Persentase \\
\hline 1 & $66,00-71,60$ & Sangat rendah & 23 & 6,1 \\
2 & $71,61-77,21$ & Rendah & 90 & 24,0 \\
3 & $77,22-82,82$ & Sedang & 133 & 35,5 \\
4 & $82,83-88,43$ & Tinggi & 97 & 25,9 \\
5 & $88,44-94,04$ & Sangat tinggi & 32 & 8,5 \\
\hline & Total & & 375 & 100 \\
\hline
\end{tabular}

Hubungan Keikutsertaan Kegiatan Ekstrakurikuler dan Prestasi Belajar Pesesrta Didik SMP Negeri Kabupaten Trenggalek

Pengujian hipotesis secara parsial ekstrakurikuler menghasilkan nilai t hitung sebesar 2,778 dengan propabilitas sebesar 0,006 . Hasil pengujian tersebut menunjukkan propabilitas < level of significance ( $=0,05)$. Hal ini berarti terdapat hubungan yang positif antara keikutsertaan kegiatan ekstrakurikuler dan prestasi belajar peserta didik SMP Negeri Kabupaten Trenggalek.

Tabel 3 Uji Hipotesis Hubungan Keikutsertaan Kegiatan Ekstrakurikuler dan Prestasi Belajar Peserta Didik SMP Negeri Kabupaten

\begin{tabular}{|c|c|c|c|c|c|}
\hline \multirow[t]{2}{*}{ Model } & \multicolumn{2}{|c|}{$\begin{array}{l}\text { Unstandardized Coef- } \\
\text { ficients }\end{array}$} & \multirow{2}{*}{$\begin{array}{c}\text { Standardized } \\
\text { Coefficients } \\
\text { Beta }\end{array}$} & \multirow[t]{2}{*}{$\mathrm{t}$} & \multirow[t]{2}{*}{ Sig } \\
\hline & $\mathrm{B}$ & Std. Error & & & \\
\hline (Constant) & 78,142 &, 823 & & 94,904 &, 000 \\
\hline Ekstrakurikuler & ,119 & 043 &, 142 & 2,778 &, 006 \\
\hline
\end{tabular}

\section{Hubungan Keikutsertaan Kegiatan Ekstrakurikuler dan Prestasi Belajar Peserta Didik SMP Negeri Kabupaten Trenggalek}

Pengujian hiportesis simultan digunakan untuk mengetahui ada atau tidaknya hubungan pada kegiatan ekstrakurikuler dengan prestasi belajar siswa SMP Negeri Kabupaten. Kriteria pengujian menyatakan jika nilai Fhitung $>$ Ftabel atau simultan kegiatan ekstrakurikuler dengan prestasi belajar siswa SMP Negeri Kabupaten. Pengujian hipotesis secara simultan menghasilkan Fhitung sebesar 7,719 dengan propabilitas sebesar 0,006 . Hasil tersebut menunjukan propabilitas $(a=0,05)$. Hal ini berarti bahwa kegiatan ekstrakurikuler ada hubungan yang positif dengan prestasi belajar siswa SMP Negeri Kabupaten. 
Tabel 4 Uji Hipotesis Hubungan Keikutsertaan Kegiatan Ekstrakurikuler dan Prestasi Belajar Peserta Didik SMP Negeri Kabupaten Trenggalek

\begin{tabular}{lccccc}
\hline Model & $\begin{array}{c}\text { Sum of } \\
\text { Squares }\end{array}$ & df & Mean Square & F & Sig. \\
Regression & 235,544 & 1 & 235,544 & 7,719 &, $006^{\mathrm{a}}$ \\
Residual & 11381,352 & 374 & 30,513 & & \\
Total & 11616,896 & 375 & & & \\
\hline
\end{tabular}

\section{PEMBAHASAN}

\section{Keikutsertaan Kegiatan Ekstrakurikuler Peserta Didik SMP Negeri Kabupaten Trenggalek}

Berdasarkan dari hasil penelitian dapat disimpulan bahwa kegiatan ekstrakurikuler SMP Negeri Kabupaten Trenggalek dalam kategori sedang. Hasil penelitian ini sesuai dengan hasil temuan dalam penelitian yang telah dilakukan oleh Partiningsih (2017), yaitu keaktifan mengikuti ekstrakurikuler Rohis peserta didik kelas VIII SMP Negeri 1 Baki pada tahun ajaran 2016/2017 terdapat pada kategori sedang.

Keikutsertaan kegiatan ekstrakurikuler disini dapat dijadikan sebagai penunjang pengembangan prestasi peserta didik. Menurut (Zulkarnain, 2015) ekstrakurikuler memiliki beberapa fungsi yaitu, (1) pengembangan, (2) sosial, (3) rekreatif, dan (4) persiapan karir. Dari pernyataan ini dapat diambil kesimpulan bahwa tujuan dan fungsi dari ekstrakurikuler secara keseluruhan adalah sebagai pengembangan aspek-aspek kemanusiaan peserta didik secara utuh seperti aspek afektif, kognitif, dan juga aspek psikomotorik, selain itu juga untuk mengembangkan minat dan bakat peserta didik yang positif, memberikan kemampuan kepada peserta didik untuk meningkatkan kemampuannya berinteraksi dengan lingkungannya.

\section{Prestasi Belajar Peserta Didik SMP Negeri Kabupaten Trenggalek}

Berdasarkan hasil penelitian dapat diketahui variabel prestasi belajar peserta didik SMP Negeri Kabupaten Trenggalek dalam kategori sedang. Hasil penelitian ini sesuai dengan hasil temuan dalam penelitian yang telah dilakukan oleh Cahyandaru (2013), yaitu hasil penelitian menunjukkan bahwa prestasi belajar peserta didik kelas XI MAN Yogyakarta II dalam kategori cukup.

Prestasi belajar menurut Arifin (1990) memiliki peran dalam keberhasilan dari belajar peserta didik. Ada beberapa faktor yang mempengaruhi peserta didik dalam mencapai prestasi belajar, menurut Suryabrata (2006) mengemukakan bahwa faktor-faktor yang dapat memepengaruhi proses belajar dan prestasi belajar dapat digolongkan menjadi dua, yaitu faktor internal dan faktor eksternal.

\section{Hubungan Keikutsertaan Kegiatan Ekstrakurikuler dan Prestasi Belajar Peserta Didik SMP Negeri Kabupaten Trenggalek}

Berdasarkan hasil dari pengetahuan dapat diketahui secara simultan variabel kegiatan ekstrakurikuler ada hubungan yang positif dengan prestasi belajar peserta didik SMP Negeri Kabupaten Trenggalek. Hasil penelitian ini sesuai dengan hasil temuan yang ada dalam penelitian yang dilakukan oleh Hardianus (2014) berdasarkan hasil analisis data penelitian, dapat disimpulkan secara simultan ada hubungan positif dari variabel kegiatan ekstrakurikuler dengan prestasi belajar siswa SMK Perindustrian Yogyakarta. Penelitian Nasehudin (2010) berdasarkan uji analisis data, dapat disimpulkan secara simultan bahwa ada hubungan yang bersifat positif antara kegiatan ekstrakurikuler dengan prestasi belajar siswa MTs. Penelitian Putra (2012) dapat disimpulkan secara simultan bahwa terdapat hubungan yang positif dan signifikan antara kegiatan ekstrakurikuler (seni musik) terhadap prestasi belajar seni 
budaya. Penelitian Cahyandaru (2013) dapat disimpulkan secara simultan bahwa terdapat pengaruh yang positif dan signifikan antara keaktifan siswa dalam kegiatan ekstrakurikuler terhadap prestasi belajar siswa. Penelitian Rusmiaty (2010) dari hasil penelitian dapat disimpulkan secara simultan bahwa kegiatan ekstrakurikuler memberikan pengaruh positif terhadap prestasi belajar siswa di MAN Pinrang. Penelitian Inriyani (2017) dari hasil penelitian diperoleh bahwa hipotesis kedua menyatakan ada pengaruh yang signifikan antara kegiatan ekstrakurikuler pada motivasi belajar. Penelitian Fatimah (2019) terdapat hubungan positif dan signifikan antara kegiatan ekstrakurikuler dengan kesiapan karir (career readness) peserta didik Kelas XI SMA Taman Siswa Teluk Betung Tahun Ajaran 2018/2019. Penelitian Shaputra (2016) dari hasil penelitian di simpulkan bahwa keaktifan siswa dalam kegiatan ekstrakurikuler mempunyai pengaruh terhadap kepribadian siswa.

Keikutsertaan kegiatan ekstrakurikuler dapat meningkatkan pengetahuan yang dimiliki oleh peserta didik baik itu dari segi kognitif, afektif, dan juga psikomotorik. Keikutsertaan kegiatan ekstrakurikuler dapat dijadikan sebagai pengembangan kreativitas yang dapat meningkatkan prestasi belajar. Prestasi belajar adalah hasil yang diperoleh selama proses pembelajaran yang mengakibatkan perubahan dalam diri individu sebagai hasil dari aktivitas belajar (Djamarah, 2012). Prestasi belajar menurut Ghufron dan Risnawati (2013) adalah hasil yang diperoleh siswa setelah melakukan aktivitas belajar yang dinyatakan dalam bentuk nilai angka atau huruf. Berdasarkan dari beberapa pendapat para ahli di atas dapat di tarik kesimpulan bahwa prestasi belajar adalah hasil yang diperoleh dari perubahan setelah melakukan aktivitas belajar dan dinyatakan dalam bentuk nilai angka ataupun huruf.

Prestasi belajar peserta didik tidak hanya cukup dari proses belajar mengajar di dalam kelas saja, hal ini menjadikan keikutsertaan kegiatan ekstrakurikuler sebagai penyeimbang dalam proses belajar mengajar. Peserta didik yang menginginkan prestasi belajar yang tinggi harus memiliki kreativitas dan keaktifan yang tinggi dari segala hal misalnya keikutsertaan kegiatani ekstrakurikuler.

\section{SIMPULAN}

Berdasarkan hasil penelitian dan pembahasan dapat disimpulkan bahwa: (1) tingkat keikutsertaan peserta didik dalam kegiatan ekstrakurikuler di SMP Negeri Kabupaten Trenggalek masuk dalam kategori sedang; (2) tingkat prestasi belajar peserta didik di SMP Negeri Kabupaten Trenggalek masuk dalam kategori sedang; (3) secara simultan terdapat hubungan yang positif antara keikutsertaan kegiatan ekstrakurikuler dan prestasi belajar peserta didik SMP Negeri Kabupaten Trenggalek.

\section{DAFTAR RUJUKAN}

Arifin, Z. (1990). Evaluasi Instruksional. Bandung: PT Remaja Rosdakarya

Cahyandaru, H. (2013). Pengaruh Keaktifan Siswa dalam Ekstrakurikuler terhadap Prestasi Belajar Siswa Kelas XI MAN Yogyakarta, (Online), (https://eprints.uny.ac.id/10525/) diakses 11 Mei 2019

Djamarah, S. B. (2012). Prestasi Belajar dan Kompetensi Guru. Surabaya: Usaha Nasional.

Fatimah, M. (2019). Hubungan Antara Kegiatan Ekstrakurikuler Dengan Kesiapan Karir (Career Readness) Siswa, (Online), (jurnal.fkip.unila.ac.id/index.php/ALIB/article/download/17857/12759) diakses 15 Juli 2019

Firdaus. (2012). Metode Penelitian. Tangerang: Jelajah Nusa.

Hardianus, D. (2014). Hubungan Kegiatan Ekstrakurikuler Dengan Prestasi Belajar Siswa Smk Perindustrian Yogyakarta, (Online), (http://eprints.uny.ac.id/25517/1/Defri\%20Hardianus\%2007504244007.pdf) diakses pada 09 april 2018

Hasibuan, J. \& Moedjiono. (2006). Proses Belajar Mengajar. Bandung: CV Remaja Rosdakarya.

Inriani, Y. (2017). Pengaruh Kegiatan Ekstrakurikuler Terhadap Prestasi Belajar IPS Melalui Motivasi Belajar, 2(7), http://journal.um.ac.id/index.php/jptpp/article/view/9685/4580

Kadir, A. (2010). Misteri Otak Kiri Manusia. Yogyakarta: DIVA Press.

Nasehuddin,A.(2010).PengaruhKegiatanEkstrakurikulerTerhadap PrestasiBelajarSiswaMTs. NegeriPagedangan, (Online), (http://repository.uinjkt.ac.id/dspace/bitstream/123456789/21502/1/AHMAD\%NASEHUDDINFTK.pdf) diakses pada 12 Maret 2018 
Partiningsih. (2017). Hubungan Antara Keaktifan Mengikuti Ekstrakurikuler Kerohanian Islam (Rohis) dengan Minat Belajar PAI Siswa Kelas VIII di SMP Negeri 1 Baki Sukoharjo Tahun Pelajaran 2016/2017, (Online), (http://eprints.iain-surakarta.ac.id/id/eprint/1212) diakses 11 Mei 2019

Putra, A. J. (2012). Pengaruh Minat dan Motivasi Siswa dalam Kegiatan Ekstrakurikuler Seni Musik Terhadap Prestasi Belajar Seni Budaya di SMPN 1 Wates, (Online), (http://eprints.ums.ac.id/28820/ig/NASKAH PUBLIKASI.pdf) diakses 11 Mei 2019

Rusmiaty. (2010). Pengaruh Kegiatan Ekstrakurikuler Terhadap Prestasi Belajar Siswa MAN Pinrang, (Online), (https://docplayer.info/67960202-Pengaruh-kegiatan-ekstrakurikuler-terhadap-prestasi-belajar-siswa-manpinrang-html) diakses 11 Mei 2019

Shaputra, L. W. (2016). Pengaruh Keaktifan Siswa dalam Kegiatan Ekstrakurikuler Terhadap Kepribadian Siswa Paket Keahlian Teknik Gambar Bangunan SMK Negeri 1 Pajangan Bantul, (Online), (journal.student.uny. ac.id/ojs/ojs/index.php/sipil/article/download/2934/2545) diakses pada 14 Juli 2019

Sugiyono. (2014). Metode Penelitian Kuantitatif, Kualitatif, dan R\&D. Bandung: Alfabeta.

Surya, M. (2007). Psikologi Pembelajaran dan Pengajaran. Bandung: Pustaka Bani Quraisyi.

Wiyono, B. B. (2007). Metodologi Penelitian (Pendekatan Kuantitatif, Kualitatif dan Action Research). Malang: Fakultas Ilmu Pendidikan Universitas Negeri Malang.

Zulkarnain, W. (2015). Layanan Khusus Peserta Didik. Malang: Universitas Negeri Malang. 